\title{
Mind Mapping Strategy in Writing Descriptive Text Implemented to Ninth Grade Students
}

\author{
David Reynaldi Hambali ${ }^{*}$
}

${ }^{1}$ SMP Sarunai Hulu Tampang, Barito Selatan, Kalimantan Tengah.

\begin{abstract}
The research was conducted to find out the effect of using mind mapping strategy on students' skill in writing descriptive text. The sample was 44 ninth grade students of SMP Sarunai Hulu Tampang by deciding class IX A as experimental group and class IX B as control group which were equally filled by 22 students to each group. The method used in this study was true experimental method, by using posttest-only control group design. The writer collected the data by conducting essay test of writing descriptive text. The writer also gave questionnaire as an additional instrument to support the data of the students in writing descriptive text. The data were analyzed using MannWhitney statistic since the data were not conform to the normal distribution. The result of this study showed that Asymp. Sig (2-tailed) was 0.000 which was lower than 0.05 . This means there is a significant effect of using mind mapping strategy on students' skill in writing descriptive text. Meanwhile, the result of the questionnaire showed that students' response toward mind mapping strategy on students' writing descriptive text was really good and positive. The students admitted that the using mind mapping strategy in English learning process could help them more easier to understand descriptive text. Also, the mind mapping was interesting and fun.
\end{abstract}

Keywords: mind mapping strategy, writing, descriptive text

\section{INTRODUCTION}

English is one of the most important elements in education to develop human sources. It is being expected to be able to make people aware about future where English will be used in all fields even now English can be found easily everywhere and every time. Crystal in McKey, (2015:7) says that English is rapidly assuming the role of a world language, and no other language has spread around the globe so extensively, making English a truly international language. Therefore, the mastery of English is a must. In Indonesia, English is an important subject in the curriculum. The students must master four skills namely listening, speaking, reading, and writing. Particularly for writing, it is being used in many aspects of global literature such as agreements in political and military, advertisement, business transaction, archiving, legal document, and newspaper. Richards and Renandya (2010: 303) stated that writing is the most difficult skill for second language and foreign language learners.

They define that writing is generating, organizing, and translating ideas into a readable text. Their statements show that learners are getting more than one process in writing. It becomes a problem when learners cannot process their ideas into a text, even sometimes they do not know what to do in the beginning of writing. That is the reason why learning strategies are needed in learning activities to help the students.

\footnotetext{
*Corresponding author: davidreyza14@gmail.com

To cite this article: Hambali, D.R. (2021). Mind Mapping Strategy in Writing Descriptive Text Implemented to Ninth Grade Students. Ebony --- Journal of English Language Teaching, Linguistics, and Literature, 1 (1) 2021, pp. 1-9.
} 
A strategy is a method that is used during the learning process. One strategy that has proven and is capable of optimizing learning outcomes is the mapping strategy called mind maps (Mind Mapping). According to Edward (2010: 64), mind mapping is the most effective and efficient way to enter, store and retrieve data from or to the brain. Mind Mapping is a way of noting the subject matter that allows students to learn writing.

A strategy popularized by Buzan (2012: 6) is an effective strategy to improve writing skills. Mind Mapping is to write the main theme as a central point and to make branches of each theme. That means the focus of learning is directed at the main theme, the finer points of the theme that is being studied, the development of each of these important points and find the relationship between any points. In this way, it can be obtained an overview of what has been known and which areas are still not yet well understood.

In this case, writing activities utilize the entire activity of the brain, namely the potency of the left brain related to logic and right brain related to the emotion. This strategy will help the students for brainstorming or to find information within the brain by combining elements of colour and symbols. As we know that colour, symbol, and picture can stimulate the students to be active and relieve their stress, then they will more quickly develop their creativity in writing.

Mind Mapping will greatly assist students in exploiting the potency of both sides of their brain. A good interaction between the two parts of the brain can trigger creativity that provides convenience in the process of writing. The students that always use and develop their potency of the brain parts will achieve an increase in some aspects, namely concentration, creativity, and understanding, then they can develop writing through mind mapping.

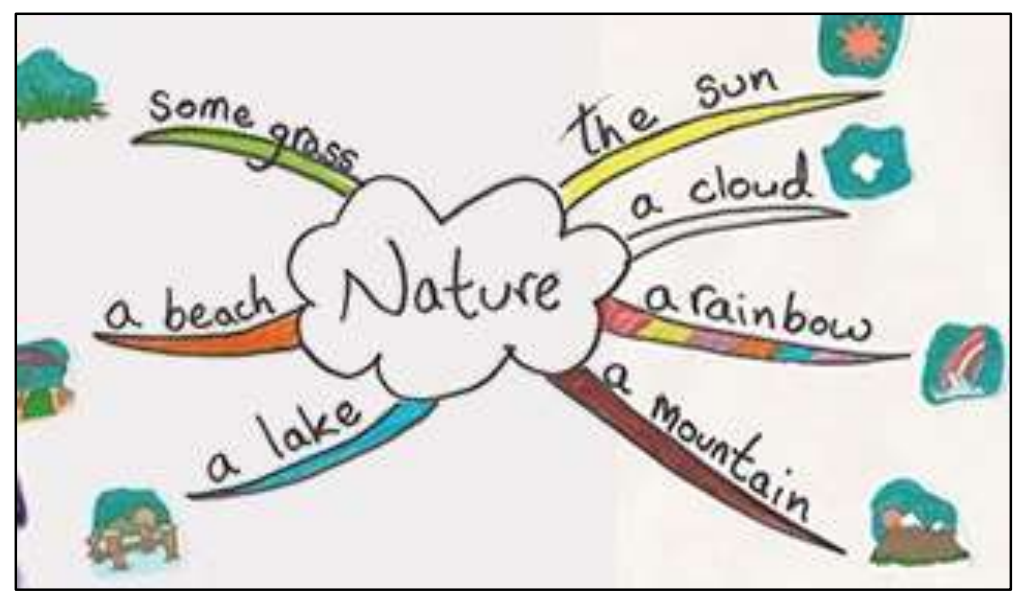

Figure 1. Mind Mapping

Buzan (2012: 21-23), suggests there are seven steps to make Mind Mapping as in the following.

1) Putting the main idea in the centre Placing the main idea or topic in the middle of page will give maximum space for other ideas to radiate out from the centre. It gives freedom to expand the ideas to any direction which is a perfect example of radiant thinking in action.

2) Using a picture or photo for the central idea Pictures have a strong impact on imagination 
and memory. It also pleases sight and keeps attention focused.

3) Using colours. The use of colour is a very good memory marker. Colours on mind mapping are not only to engage the right brain active, but also to help the grouping information.

4) Connecting main branches to the centre picture and connect the second and third branches to the first and second. Trying to connect main branches to the centre picture and connect the second and third branches to the first and second, and so on because the brain works according to the association. Human brain likes to relate two or more things all at once. The connections among branches make it easier to understand and remember.

5) Making a curve line connector, not a straight line Draw a connector curve line in each branch to make it more attractive and beautiful.

6) Using one key word for each line A single key word gives more energy and flexibility for mind mapping.

7) Using pictures An image has a lot of meaning is because it can replace a keyword or simply reinforce key words that have been written previously.

The role of teacher in implementing Mind Mapping strategy can be started by planning the content of their writing and its outline. In this case, there are two common ways that are usually used in this stage. They are brainstorming and guided task. The brainstorming can be applied in pairs or group discussion. In the discussions, they can share anything that can be used as their writing topic or content. Meanwhile, the guided task are more related to some activities that will lead them to find their ideas to write.

Then, the teacher may encourage the students to draft, reflect, and revise. In this stage the student have to make a draft and finish it as a proper writing or text. The teacher should check their draft and help them to reflect and revise it. Teacher can give an instruction for the students to check their draft to each other. It will lead them to collaborative writing. In this process, they will work collaboratively with their classmates in order to produce a good writing. They must give respond to each other's drafts in terms of language and content and give suggestion to each other. They will share any ideas that are significant to their writing.

And, the teacher responds to the students' writing. This step is important because the teacher's respond can give a big effect to students. A wrong respond can decrease the spirit of the students; otherwise a good respond can stimulate the student to give more effort. The first way the teachers can do is talking to the students in a group while the others are still working on their own. The second way is giving reformulation to them. In this way, the teacher writes their own revision of a good writing. It will be crucial for the student as a comparison with their work. The last way is conducting peer response. It will be really pleasant for them because they can discuss together.

Many studies look into mind mapping strategy in teaching writing. Some of them, Riyanto (2013), for instance, found that the application of the mind mapping strategy in mastering science learning subjects in full day school based is able to increase students' learning mastery by level of student learning completion reaches 93.75. In addition, Sudarmanto (2013) found that there are differences in the use of mind mapping models and problem based learning on student economic learning outcomes. This is proved by Anova 
test obtained by Sig. $0.003<0.05$ that indicates significant differences in the use of mind mapping models and problem based learning on student economic learning outcomes. The other finding is that the effectiveness of the mind mapping model and problem based learning is 0.78 which means the mind mapping learning model is more effective than the problem based learning model.

From those two studies, it can be summarized that mind mapping strategy is very helpful for teachers to facilitate their students in learning. In relation to this research, its objective aims to find out the effect of using mind mapping strategy on students' ability in writing descriptive text at ninth grade students of the secondary school.

\section{METHODS}

This research belongs to true experimental design. The researcher chose a control and experimental groups of the ninth grade students in which the experimental group received the treatment of using Mind Mapping strategy while the control group did not. The sample was 44 ninth grade students of SMP Sarunai Hulu Tampang by deciding class IX A as experimental group and class IX B as control group which were equally filled by 22 students to each group.

This research was developed to test the hypotheses below:

$\left(\mathrm{H}_{0}\right)$ : There is no effect of using Mind Mapping strategy on students' skill in writing descriptive text.

$\left(\mathrm{H}_{\mathrm{a}}\right)$ : There is a significant effect of using Mind Mapping strategy on students' skill in writing descriptive text.

The instruments used for this research were writing test and the questionnaires. The writing test was in the form of essay test. The students were asked to write a simple descriptive text of one of their family members. Students must describe his/ her physical appearance, and any other unique things from the person. Then students' writings were rated based on writing aspects such as organization, grammar, vocabulary, and mechanics by the rubric scale ranging from 1 to 4 representing the poor aspect to the very good one. Then, the other instrument is the questionnaire used to find the students' response related to mind mapping strategy used by the teacher in learning descriptive text which was only given to the experimental group since the group received the mind mapping strategy.

In analysing the data, researcher used the non-parametric statistic named MannWhitney. This statistical analysis data chosen is by the reason that the data of students' scores were not normally distributed using the Liliefors normality test. The sig-values calculated by SPSS show 0.04 for the experimental group, and 0.13 for the control group. This means both sig-values are lower than 0.05 which indicate that scores attained by those groups are not normally distributed. In addition, the researcher also tested the coefficient reliability of the test by Pearson reliability which defined the R-value is 0.899 . This value belongs to the qualification of good reliability. Therefore, the test instrument of this research is confirmed to be reliable. 


\section{RESULTS}

The result of tests from the two groups was compared on the table below to find out the effect of using the mind mapping strategy on writing descriptive text.

Table 1. The result of test by the experimental group

\begin{tabular}{lccccccc}
\hline No. & $\begin{array}{c}\text { Students } \\
\text { Code }\end{array}$ & $\begin{array}{c}\text { Organi- } \\
\text { zation }\end{array}$ & Grammar & $\begin{array}{c}\text { Vocabu- } \\
\text { lary }\end{array}$ & $\begin{array}{c}\text { Mecha- } \\
\text { nics }\end{array}$ & $\begin{array}{c}\text { Total } \\
\text { points }\end{array}$ & $\begin{array}{c}\text { Scores } \\
\text { attained }\end{array}$ \\
\hline 1. & E1 & 4 & 3 & 2 & 2 & 11 & 76.25 \\
\hline 2. & E2 & 4 & 3 & 3 & 1 & 11 & 77.50 \\
\hline 3. & E3 & 4 & 2 & 3 & 3 & 12 & 78.75 \\
\hline 4. & E4 & 4 & 4 & 2 & 4 & 14 & 90.00 \\
\hline 5. & E5 & 3 & 2 & 2 & 2 & 9 & 60.00 \\
\hline 6. & E6 & 4 & 2 & 3 & 4 & 13 & 82.50 \\
\hline 7. & E7 & 4 & 3 & 3 & 3 & 13 & 85.00 \\
\hline 8. & E8 & 4 & 2 & 3 & 4 & 13 & 82.50 \\
\hline 9. & E9 & 4 & 2 & 2 & 1 & 9 & 66.25 \\
\hline 10. & E10 & 4 & 2 & 3 & 4 & 13 & 82.50 \\
\hline 11. & E11 & 4 & 3 & 2 & 2 & 11 & 76.25 \\
\hline 12. & E12 & 3 & 2 & 2 & 2 & 9 & 60.00 \\
\hline 13. & E13 & 4 & 2 & 3 & 4 & 13 & 82.50 \\
\hline 14. & E14 & 4 & 3 & 2 & 2 & 11 & 76.25 \\
\hline 15. & E15 & 4 & 2 & 2 & 1 & 9 & 66.25 \\
\hline 16. & E16 & 4 & 3 & 2 & 2 & 11 & 76.25 \\
\hline 17. & E17 & 4 & 2 & 2 & 1 & 9 & 66.25 \\
\hline 18. & E18 & 4 & 2 & 3 & 4 & 13 & 82.50 \\
\hline 19. & E19 & 4 & 3 & 3 & 1 & 11 & 77.50 \\
\hline 20. & E20 & 4 & 3 & 3 & 1 & 11 & 77.50 \\
\hline 21. & E21 & 4 & 3 & 2 & 2 & 11 & 76.25 \\
\hline 22. & E22 & 4 & 2 & 2 & 1 & 9 & 66.25 \\
\hline & Total & $\mathbf{8 5}$ & $\mathbf{5 5}$ & $\mathbf{5 4}$ & $\mathbf{5 2}$ & $\mathbf{2 4 6}$ & $\mathbf{1 5 7 6 . 2 5}$ \\
\hline
\end{tabular}

Based on table 1, the test scores on writing descriptive text of the experimental group are described as followed:

1. In the aspect of organization (the generic structure of descriptive text), the result of the test after the treatment showed improvement in students' writing descriptive text. The descriptive texts were in a complete form; either the identification or the description.

2. In the aspect of grammar (language feature and other agreement of the text), the result of the test showed that students' writing of descriptive text in a good grammar; grammatical or agreement accuracies frequently occurred in the students' descriptive text.

3. In the aspect of vocabulary (choosing of words and/or word forms), the result of the test showed that even there was a few misuse of vocabularies, but those did not affected the meaning of the text. 
4. The last aspect is the mechanic (spelling, the use of punctuation and capitalization) the result of the test showed that students' writing of descriptive text showed that students used the correct spelling, punctuation and capitalization.

Table 2. The result of test by the control group

\begin{tabular}{lccccccc}
\hline No. & $\begin{array}{c}\text { Students } \\
\text { Code }\end{array}$ & $\begin{array}{c}\text { Organi- } \\
\text { zation }\end{array}$ & $\begin{array}{c}\text { Arammar } \\
\text { Espects rated }\end{array}$ & $\begin{array}{c}\text { Tocabu- } \\
\text { lary }\end{array}$ & $\begin{array}{c}\text { Mecha- } \\
\text { nics }\end{array}$ & points & $\begin{array}{c}\text { Scores } \\
\text { attained }\end{array}$ \\
\hline 1. & E1 & 4 & 3 & 1 & 1 & 9 & 67.50 \\
\hline 2. & E2 & 1 & 1 & 2 & 2 & 6 & 33.75 \\
\hline 3. & E3 & 4 & 1 & 1 & 3 & 9 & 62.50 \\
\hline 4. & E4 & 2 & 1 & 1 & 1 & 5 & 35.00 \\
\hline 5. & E5 & 2 & 1 & 2 & 1 & 6 & 40.00 \\
\hline 6. & E6 & 4 & 1 & 4 & 4 & 13 & 81.25 \\
\hline 7. & E7 & 4 & 1 & 1 & 4 & 10 & 66.25 \\
\hline 8. & E8 & 2 & 2 & 1 & 1 & 6 & 41.25 \\
\hline 9. & E9 & 4 & 1 & 1 & 2 & 8 & 58.75 \\
\hline 10. & E10 & 2 & 2 & 1 & 1 & 6 & 41.25 \\
\hline 11. & E11 & 2 & 1 & 1 & 1 & 5 & 35.00 \\
\hline 12. & E12 & 2 & 1 & 2 & 1 & 6 & 40.00 \\
\hline 13. & E13 & 2 & 2 & 2 & 2 & 8 & 50.00 \\
\hline 14. & E14 & 2 & 2 & 1 & 1 & 6 & 41.25 \\
\hline 15. & E15 & 2 & 2 & 2 & 2 & 8 & 50.00 \\
\hline 16. & E16 & 2 & 1 & 1 & 1 & 5 & 35.00 \\
\hline 17. & E17 & 1 & 1 & 2 & 2 & 6 & 33.75 \\
\hline 18. & E18 & 4 & 1 & 1 & 3 & 9 & 62.50 \\
\hline 19. & E19 & 4 & 3 & 1 & 1 & 9 & 67.50 \\
\hline 20. & E20 & 2 & 2 & 1 & 1 & 6 & 41.25 \\
\hline 21. & E21 & 4 & 3 & 1 & 1 & 9 & 67.50 \\
\hline 22. & E22 & 2 & 2 & 1 & 1 & 6 & 41.25 \\
\hline & Total & $\mathbf{5 2}$ & $\mathbf{3 0}$ & $\mathbf{2 9}$ & $\mathbf{3 5}$ & $\mathbf{1 4 6}$ & $\mathbf{9 2 1 . 2 5}$ \\
\hline
\end{tabular}

Based on the data on table 2, the test scores on writing descriptive text of the control group are described in the following.

1. In the aspect of organization (the generic structure of descriptive text), the result of the test showed that students' writing descriptive text not in a good order. The writing were not in a complete form; either the identification or the description.

2. In the aspect of grammar (language feature and other agreement of the text), the result of the test showed that students' writing of descriptive text not in a good grammar; grammatical or agreement inaccuracies frequently occurred in the students' descriptive text.

3. In the aspect of vocabulary (choose of words and/or word forms), the result of the posttest could be understood that the students' knowledge of words and word forms in the descriptive text are very poor. 
4. The last aspect is the mechanic (spelling, the use of punctuation and capitalization) the result of the test showed that students' writing of descriptive text were dominated by errors of spelling, punctuation and capitalization.

Then, scores from two groups on table 1 and table 2 are analyzed to determine whether the null hypothesis would be rejected or not. The following is the result of statistical data calculation by SPSS of the Mann-Whitney nonparametric statistics.

Table 3. Mann-Whitney test

\begin{tabular}{ll} 
& Posttest \\
\hline Mann-Whitney U & $\mathbf{3 5 . 0 0 0}$ \\
\hline Wilcoxon W & 245.000 \\
\hline$Z$ & -4.675 \\
\hline Asymp. Sig. (2-tailed) & $\mathbf{. 0 0 0}$ \\
\hline
\end{tabular}

Based on the result in table 3, the value of Asymp. Sig (2-tailed) is 0.000 which is lower than 0.05. This means the Ho hypothesis is rejected and $\mathrm{Ha}$ is accepted. As a result, there was a significant effect of using mind mapping strategy on students' skill in writing descriptive text at the ninth grade students.

In addition, the students also gave their responses about mind mapping strategy by answering 10 questions of the questionnaire. The following is the sum of students answer in percentages for each question.

Table 4. Questionnaire result

\begin{tabular}{|c|c|c|c|}
\hline \multirow{2}{*}{ No. } & \multirow{2}{*}{ Questions } & \multicolumn{2}{|c|}{ Answers in (\%) } \\
\hline & & Yes & No \\
\hline 1. & $\begin{array}{l}\text { Do you understand the generic structure (Identification and } \\
\text { Description) of the descriptive text in English? }\end{array}$ & $77 \%$ & $23 \%$ \\
\hline 2. & Do you know the language feature of descriptive text? & $86 \%$ & $14 \%$ \\
\hline 3. & Do you think English lessons is one of the most difficult subjects? & $41 \%$ & $59 \%$ \\
\hline 4. & $\begin{array}{l}\text { Does using mind mapping strategy make you always want to } \\
\text { involve in learning how to write descriptive text? }\end{array}$ & $82 \%$ & $18 \%$ \\
\hline 5. & $\begin{array}{l}\text { Do you think learning using mind mapping strategy make you } \\
\text { excited to write descriptive texts? }\end{array}$ & $95 \%$ & $5 \%$ \\
\hline 6. & $\begin{array}{l}\text { Do you want the mind mapping strategy to be used in other } \\
\text { teaching materials of English? }\end{array}$ & $73 \%$ & $27 \%$ \\
\hline 7. & $\begin{array}{l}\text { Do you think learning by using mind mapping strategy make you } \\
\text { understand more about how to write good and proper descriptive } \\
\text { text? }\end{array}$ & $64 \%$ & $36 \%$ \\
\hline 8. & $\begin{array}{l}\text { Does mind mapping strategy make you more diligent to write } \\
\text { descriptive text in English? }\end{array}$ & $86 \%$ & $14 \%$ \\
\hline 9. & $\begin{array}{l}\text { Do you think by using mind mapping strategy make you easier to } \\
\text { understand descriptive text? }\end{array}$ & $73 \%$ & $27 \%$ \\
\hline
\end{tabular}




$\begin{array}{llll}\text { 10. Do you have any problems or difficulties writing descriptive text } & 18 \% & 82 \% \\ \text { after you learn it through mind mapping strategies? } & & \end{array}$

Based on the result of the questionnaire on table 4, all students' answers supported the statistical data result that using Mind Mapping strategy on writing descriptive text positively facilitated students in learning descriptive text. This can be viewed from the percentages of students answers ranging from $64 \%$ to $95 \%$ that mind mapping strategy is exciting, assisting, and being easier for students to learn descriptive text. In addition, it is about $82 \%$ students admitted that they had no problems or even difficulties writing descriptive text after being facilitated by the mind mapping strategy.

\section{DISCUSSION}

From the previous interview with the English teachers of SMP Sarunai Hulu Tampang, the researcher found that the students had difficulties in writing descriptive text especially vocabulary and grammar. The students' writing of descriptive text not in a good grammar; in which grammatical or agreement inaccuracies frequently occurred in the students' writing.

In two treatments made by the researcher, there were found that the experimental group and control group got the same problems as stated by the teacher of SMP Sarunai Hulu Tampang. During the treatment, each group gave different performance in writing. Students in the experimental group gave positive results since the researcher taught them using mind mapping strategy. The strategy helped them develop ideas to write descriptive text enthusiastically. The students even showed their interest when the researcher asked them to discuss about the mind mapping before starting to write. They shared information from the mind mapping with their friends in order to make a good descriptive text.

Then, the researcher found that learning process in the experimental group was fun. Meanwhile, the students in the control group that were taught using a conventional way showed different learning situation. They were passive and they just listened to the teacher's explanation on the material. Their participation in the learning process was lower than the students in experimental group. When the researcher evaluated both group through giving a test by asking them to write a descriptive text, the researcher found that the experimental group showed better outcome than the control group.

It is also in line with the students' responses from the questionnaire given to the experimental group. Most of the students agreed that the use of mind mapping strategy can make them feel more enthusiastic, motivated, and encouraged to learn more about writing descriptive text. In addition, students are easier to understand language feature and generic structure of the descriptive text after the treatment given. In this regard, this research also confirms Riyanto's (2013) that mind mapping strategy can facilitate students learning especially in writing skill. Also, this research result supports Wijaya's (2016) that that mind mapping strategy is effective to improve students' ability in writing skill.

\section{CONCLUSION}

To conclude that mind mapping strategy has significant effect on students' skill in writing descriptive text at the ninth grade students. The result of treatment using this strategy showed 
an improvement scores of students in experimental group which is far different with students in control group without receiving the treatment. This is also supported by the data of students' responses in the questionnaire where positive impacts admitted by students during and after using the mind mapping strategy. During implementing the strategy students felt more enthusiastic, motivated, and encouraged to learn more about descriptive texts. Also, after implementing the strategy they have been more understanding how language features and generic structures of descriptive text are in the descriptive text.

\section{REFERENCES}

Arikunto, S. (2010). Prosedur Penelitian Suatu Pendekatan Praktik. Jakarta: Rineka Cipta

Brown, H. D. (2014). Principles of Language Learning and Teaching. $6^{\text {th }}$ ed., Pearson Education.

Buzan, T. (2012). Buku Pintar Mind Mapping. Jakarta: Gramedia Pustaka Utama.

Edward, C. (2010). Mind Mapping untuk Anak Sehat dan Cerdas. Yogyakarta: Sakti.

McKay, S . (2015). Teaching English As An International Language: Implication for Cultural

Richards, J. C. \& Renandya, W. A. (2010). Methodology in Language Teaching: An Anthology of Current Practice. Cambridge: Cambridge University Press.

Riyanto, B. (2013). Effect of the Mind Method Mapping of Natural Science Completion in Full Day School Students at Nur Hidayah Integrated Islamic Elementary School Surakarta Academic Year 2012/2013.Universitas Tunas Pembangunan Surakarta

Sudarmanto, R. G. (2013). Learning Mind Mapping and Problem Based Learning in Middle School. Univesitas Lampung

Wijaya, A. K. (2016). The Effect Of Using Mind Mapping On The Writing Comprehension Ability Of The Tenth Grade Students At SMA Tiga Maret Yogyakarta. Universitas Yogyakarta. 